\title{
Centred Discourse, Decentred Practice: The Relational Production of Russian and Chinese 'Rising' Power in Central Asia
}

John Heathershaw, University of Exeter

Corresponding Author

@Heathershaw J

ORCID: 0000-0002-9818-1860

John Heathershaw is Associate Professor of International Relations at the University of Exeter. He convenes the Exeter Central Asian Studies (ExCAS) research network and directs its Central Asian Political Exiles ( $\mathrm{CAPE}$ ) project. He is a board member of the European Society for Central Asian Studies (ESCAS) and chair of the organising committee for ESCAS's 2019 conference which will be held in Exeter. Heathershaw's most recent books include Dictators Without Borders (Yale 2017) and Paradox of Power (Pittsburgh 2017).

Catherine Owen, University of Exeter

@CatOwenExeter

ORCID: 0000-0003-4520-777X

Catherine Owen is British Academy Postdoctoral Fellow in the Department of Politics at the University of Exeter. Prior to her award, she was Lecturer in the Department of History and Civilization at Shaanxi Normal University, Xi'an, China. Owen has held Visiting Fellowships at the European University at St Petersburg, Fudan University Shanghai, and the St Petersburg branch of the Russian Academy of National Economy and Public Administration. Her work has been published in a variety of Area Studies, Comparative Politics and International Relations journals, including Slavic Review, Government and Opposition and Review of International Studies.

Alexander Cooley, Barnard College, Columbia University @CooleyOnEurasia

Alexander Cooley is the Claire Tow Professor of Political Science at Barnard College and Director of Columbia University's Harriman Institute for the Study of Russia, Eurasia and Eastern Europe. His books include Dictators without Borders (Yale 2017), Ranking the World (Cambridge 2015) and Great Games, Local Rules (Oxford 2012). 


\title{
Centred Discourse, Decentred Practice:
}

\section{The Relational Production of Russian and Chinese Rising Power in Central Asia}

\author{
John Heathershaw, Catherine Owen and Alexander Cooley
}

University of Exeter and Columbia University

\begin{abstract}
This paper challenges dominant understandings of 'rising powers' by developing a decentred, relational account of Russia and China in Central Asia. We ask whether Moscow and Beijing's regional integrative strategies do not guide, but are rather led by, everyday interactions among Russian and Chinese actors, and local actors in Central Asia. Rising powers, as a derivative of 'Great Powers', are frequently portrayed as structurally comparable units that concentrate power in their executives, fetishize territorial sovereignty, recruit client states, contest regional hegemony, and explicitly oppose the post-1945 international order. In contrast, we demonstrate that the centred discourse of Eurasian integration promoted by Russian and Chinese leaders is decentred by networks of business and political elites, especially with regard to capital accumulation. Adopting Homi K Bhabha's notion of mimicry (subversion, hybridity) and J.C. Scott's conception of mētis (local knowledge, agency), and using examples of Russian and Chinese investments and infrastructure projects in Central Asia, we argue that in order to understand centring discourse we must look to decentring practices at the periphery; that is, rising power is produced through on-going interactions between actors at the margins of the state's hegemonic reach.
\end{abstract}

\section{KEYWORDS}

Rising Power; Russia; China; Central Asia; State Transformation; Mimicry; Mētis 


\section{Introduction}

In the early twentieth century, British political geographer Halford Mackinder claimed that the centre of the Eurasian landmass was the 'geographical pivot of history'. A century later, MacKinder's assertion of the significance of Central Asia is once again seductive. ${ }^{1}$ New schemes to tessellate the region with communications and economic infrastructure abound, and the region's two 'rising powers' - Russia and China - are the central actors in these developments. Beijing's much-heralded Silk Road Economic Belt (SREB) project, the landbased component of the Belt and Road Initiative (BRI) launched in 2013, proposes a network of high-speed railways, airports and roads, as well as energy-related infrastructure that will link Chinese markets with European consumers. ${ }^{2}$ Russia, Central Asia's post-imperial power, has championed the Eurasian Economic Union (EAEU), the region's first common market, established in 2014 with the four post-Soviet states most closely aligned to Moscow (Kazakhstan, Belarus, Armenia and Kyrgyzstan).

However, inherent within the notion of a 'New Great Game' are problematic assumptions of the perceived players (and, by extension, rising powers) as coherent, unitary, Westphalian actors who enact power upon their small Central Asian neighbours. MacKinder's present-day disciples often overlook the confluence of old local rules with new offshore connections, which set the terms under which politico-military competition between states takes place. ${ }^{3}$ In fact, a great deal of the wider geopolitics of Central Asia may be obscured by an exclusive focus on the actions of Beijing and Bishkek, Moscow and Tashkent.

We challenge this dominant narrative on the nature of rising state power along two lines. First, despite the image of rational, centralised, foreign policy-making processes desired by domestic elites, the primary actors in today's alleged game are not states acting in the national interest, 
but capital-owning elites, foreign and local companies, and labour. Second, rather than conceiving of power as a linear, zero-sum commodity, imposed by a dominant upon a subordinate actor, as is found in many studies of rising powers, we see power as produced relationally in specific situations through the practices of on-going interactions between locally situated actors.

We follow these two lines of critique by developing a practice-based account of the international politics of Central Asia that begins with an understanding of state power as fundamentally fragmented and decentred. Processes of globalisation and the marketisation of state bureaucracies are driving this decentring of power in Russia and China away from Moscow and Beijing towards local actors operating at the state's periphery. As a result, centrally articulated policy towards Central Asia is often novel, occasionally incoherent, and frequently employed to justify operations that have already occurred and over which the central state had limited control. 'Decentring' here is used not as a normative preference and strategy of government in the wake of New Public Management, ${ }^{4}$ but as an analytical conceptualization of the processes of state transformation wrought by the incorporation of market logic into state bureaucracies. $^{5}$

Drawing on earlier work which explored the political-economic and regime security imperatives of the decentred post-Soviet state, ${ }^{6}$ and which linked post-Western powers to postcolonial mimicry in Central Asia, ${ }^{7}$ we extend our analysis by demonstrating that the discursive claim to be a 'rising' or 'great' power is intertwined with and produced through decentred, localised practices of two types. First, we identify practices of mimicry which are derived from the concept of Homi K. Bhabha and extended by L.H.M. Ling to refer to practices of, first, emulation and, second, hybridisation of the institutions and discourses of dominant 
actors by subordinates. Second we deploy the concept of mētis which J.C. Scott uses to denote everyday practices of local knowledge, 'knack', agency and subversion, especially with regard to capital accumulation. This interpretive framework enables us to foreground the relationship between the centred state discourse and decentred practices of Russian and Chinese actors in Central Asia. The Russian government's discursive claim to great power status in Central Asia rests on the various local deals struck to create buy-in to the EAEU and bilateral Russian initiatives. In the case of China, it is the SREB that provides symbolic cover for Chinese business' capital accumulation and the creation of new labour markets and trade routes for its expanding economy. ${ }^{8}$ The decentred practices for both include the activities of elite interpersonal power networks and agencies, semi-autonomous corporations and various 'soft power' organisations. These entities often operate independently of and sometimes in contradiction to central government policy, often requiring political leaders to make post hoc rationalisations of activities carried out under their auspices.

In considering Russian and Chinese practices in Central Asia under the same framework, we do not wish to suggest equivalence. Clearly, the historical and colonial legacies of both states in the region, their relationships to Western models of political organisation, and the extents to which their state bureaucracies have adopted market principles, mean that they exhibit very different forms and degrees of mimicry, the more culturally and historically contingent of the two concepts we propose. Nevertheless, we seek to demonstrate that the decentred forms of power that interact with and produce the centred discourse are common to both Russia and China in Central Asia (and, indeed, potentially elsewhere). Rather than offering a straightforward comparison of Russian and Chinese practices, we present mimicry and mētis as heuristic tools to aid understanding of the ways in which power is (re)produced through 
interactions among unequal actors across scales and borders, and thereby advance a more nuanced understanding of how states 'rise'.

The essay is structured in four parts. First, we consider the elite discourses of the EAEU and SREB as demonstrative of Moscow and Beijing's self-projection as centred Westphalian actors; and, second, we advance a relational theory of rising powers, situated in conditions of globalisation and enacted through post-colonial practices of mimicry and mētis. Parts Three and Four illustrate our theory using case studies of Russian and Chinese investments and transregional economic projects in Central Asia, evidenced in their commercial and political practices.

\section{Centred Projections of 'Rising' Power in Central Asia}

This section explores the centred discourses of Russian and Chinese policy-makers towards Central Asia, and argues that they are performative of parallel and competing grand strategies which ape one another in their claims to great power status (Russian: velikaya derzhavnost'.

Chinese: da guo, 大国). At the same time, as demonstrated below, these strategies effectively misrepresent decentred practice and power relations.

Conventional analyses of Russia and China in Central Asia often present China as the dominant power: Russia as an economic actor has been displaced by an increasingly wealthy China. ${ }^{9}$ At first glance, these analyses appear correct: in Central Asia, Russian regional investment was overtaken by China in $2008 .{ }^{10}$ Nevertheless, it is misleading to suggest, as Mearsheimer does, that Russia is a 'declining' power - especially in the Central Asian context. ${ }^{11}$ Russian power draws its strength from Soviet-era political-cultural commonalities 
and legacies, which provoke formal mimicry in business and politics and are the basis of the practical knowledge which sustains political-economic relations (mētis). The differing types of Russian and Chinese power are reflected in the discourses of Eurasian integration articulated by Vladimir Putin and Xi Jinping.

Since his first term in power, Putin has sought to promote integrative projects in the Eurasian region, and there have existed a number of institutional precursors to the EAEU. ${ }^{12}$ Treaties establishing the EAEU in its current form were signed by Belarus, Kazakhstan and Russia in May 2014, and entered into force on 1 January 2015. Armenia and Kyrgyzstan's accession came into force in January and August 2015 respectively. Thus, at the time of writing, the contemporary EAEU has been operative for about four years. Its economic agenda involves the removal of non-tariff barriers, the creation of common utilities markets, and the standardization of policies in such spheres as transport, public procurement and financial services. ${ }^{13}$

The key text in which Putin articulates his vision for Eurasian integration is a 2011 article published in the newspaper Izvestiya. Here, Putin claimed that the project is 'a historic milestone not only for our three countries, but for all states in the post-Soviet space'. ${ }^{14}$ The article links the various integrative projects initiated since the collapse of the USSR - the Commonwealth of Independent States (CIS), the Collective Security Treaty Organization (CSTO), the Eurasian Economic Community (EurAsEC) - in a teleological process culminating in the present-day EAEU. Five years later, in his 2016 keynote address at the St Petersburg Economic Forum, Putin set out a vision for the EAEU to act as an institutional 'bridge' between Europe and Asia by seeking to form partnerships both with 'Eastern' countries, such as China, India, Iran and Pakistan, and with European countries. ${ }^{15}$ The speech consistently portrays the EAEU as a coherent and strategic geopolitical actor, capable of 
enabling complex trading relations, conducting regulatory oversight and governing technological innovation. ${ }^{16}$

Similar discursive tropes depicting an inevitable teleology towards the contemporary state of affairs are found in Chinese elite discourse concerning the SREB. However, in contrast to Putin's post-imperial emphasis on unity, Xi's legitimating narrative of 'connectivity' reinforces the idea of co-operation among independent sovereign states. As reflected in Xi's discourse, the project is marketed as an open and inclusive project: any state with an interest in the initiative - or in one of the institutions summarized under the BRI - can become part of it. As Jones and Zeng argue, this openness is driven by the need for generating new markets for the surplus capacity of Chinese industry, primarily its state-owned enterprises. ${ }^{17}$

Chinese President Xi Jinping first presented the idea in a 2013 speech at Nazarbayev University in Astana, Kazakhstan. His address is couched in banal nationalist discourse that positions his contemporary agenda as a form of historical continuity: 'Today, as I stand here and look back at [the establishment of the ancient silk road], I could almost hear the camel bells echoing in the mountains and see the wisp of smoke rising from the desert' ${ }^{18}$ However, the strategy paper released in 2015, Vision and Actions on Jointly Building Silk Road Economic Belt and 21stCentury Maritime Silk Road, indicated that the precedent on which SREB was based was not long-lived friendship but commercial and investment interests of SOEs dating from the era of Deng Xiaoping. ${ }^{19}$ The plan was the post hoc gloss covering diverse and competing infrastructure and investment projects. Depending on how 'Central Asia' is understood, perhaps 4 of these 11 pass through the region. ${ }^{20}$ 
In his opening address at the Belt and Road Forum in May 2017, Xi Jinping linked the BRI both to the Chinese silk roads that crossed Eurasia during antiquity and to a new China-led model of global development spanning policy spheres ranging from infrastructure development and technological innovation to environmental protection and cultural exchange. Xi attributes an array of projects across Eurasia and South East Asia, many of which had long been in the offing, to BRI. These include Indonesia's high speed rail programme has been under consideration since before 2010, and contracts for the construction of the Addis Ababa Djibouti railway were awarded to two Chinese SOEs in 2011. Other activity associated with the 11 routes and corridors dates back to the late-1980s. ${ }^{21}$

While the two visions of Eurasian integration emerge from very different economic and historical contexts they both possess a centred discourse of grand strategy, which feature two common elements. First, a claim to strong historical continuity from which both projects are portrayed to derive their legitimacy, and second, a strong emphasis on central coherence. ${ }^{22}$ These two claims are performative. In the case of Russia, this discourse feeds into what Stefanie Ortmann has termed 'the myth of the strong state', where spectacular international performances of Russian stateness during the 2000s are best seen as a process of state-building, rather than a coherent geopolitical strategy. ${ }^{23}$ Arguably, the same can be said for China, keen to be seen as the champion of developing countries and to regain lost status after the colonial encounters of the $19^{\text {th }}$ Century. However, a focus on great power discourse alone cannot make sense of state transformation processes, which are constituted through everyday practices of interaction, subversion and contestation that take place far from the centre's reach, and remain inscrutable to realist, liberal, constructivist, post-structuralist and even neo-Gramscian approaches. $^{24}$ 


\section{Decentred Rising Powers and Postcolonial International Relations}

We advance a relational account of rising powers as decentred actors that employ postcolonial practices of mimicry and mētis. This decentred approach is not particular to postcolonial spaces or rising powers but a long-standing and more general critique. Accelerated via processes of globalisation, these processes of decentring may be observed in states of the global North and South, in both great powers and small. ${ }^{25}$ Here, power is not a quantifiable entity, as traditionalists claim, but is dispersed across agencies, institutions, and individuals and produced through interactions among them.

Hameiri and Jones observe that, "the central state shifted from a "command and control" model based on direct intervention to secure economic, social and political objectives to a "regulatory" model, whereby central government merely sets broad targets and regulations for diverse public and private actors' ${ }^{26}$ As a result, policy areas formerly administered by government have been displaced by a diversity of actors, including domestic and multi-national corporations, charities and citizens groups, and semi-independent agencies. ${ }^{27}$ Our account maps how parts of the state, industry and business create transnational and international connections that exist in dialogical relationship with the foreign policymaking by central governments. As we elaborate below, a postcolonial move reveals how actors associated with rising powers' centres in Moscow and Beijing employ formal mimicry in their discursive and institutional emulation of established powers, substantive mimicry in the subversive or hybrid meanings and identities they frequently attach to these new institutions, and practical mētis (cunning, evasion) at the everyday level. $^{28}$ In turn, relations between risers and fallers, powerful patrons and their clients, dominant discourses and practices, between institutions and individuals, must be at front and centre of analysis. 
The structure of both Chinese and Russian state bureaucracies bear hallmarks of decentralization, internationalization and fragmentation. In the Chinese case, Hameiri and Jones argue that as central government implemented policies of fiscal decentralisation and deregulation to facilitate global economic integration, subnational agencies, institutions and companies in the public and private sectors have increasingly developed autonomous interests with a transnational dimension, and have become difficult for central government to manage. ${ }^{29}$ The consequence of this shift in statehood leads indirectly to its promotion elsewhere: 'as China's economy expands beyond its borders, so does the "governance frontier" of its state apparatuses' 30

In the Russian case, the state initially appears much more centred on a new patronal form of rule as Putin brought the oligarchs who dominated particular economic sectors under control after $2000,{ }^{31}$ reigning in the 'paradiplomacy' that had been widespread under Yeltsin. ${ }^{32}$ However, internationalizing and fragmenting trends, driven by the kleptocratic networks of Putin and his inner circle, ${ }^{33}$ continue alongside Putin's purported efforts to restore Russia as a 'Great Power' or Velikaya Derzhava. ${ }^{34}$ Global assemblages of the international financial system - particularly the linkage to secretive 'offshore' jurisdictions - were instrumental to this process as witnessed in the Russian state's former Soviet clients in Central Asia ${ }^{35}$ and in the transformation of its organised crime networks into transnational business actors. ${ }^{36}$

The practices by which power relations are produced in regional contexts are no less entrenched in legacies of imperialism and colonialism (of either the aristocratic-mercantilist or state socialist kind). The recent turn towards a practice-based approach to IR is consistent with a postcolonial optic. 'World politics,' Adler and Pouliot argue, 'can be understood as structured by practices, which give meaning to international action, make possible strategic interaction, 
and are reproduced, changed, and reinforced by international action and interaction'. ${ }^{37}$ Curiously, Adler and Pouliot's volume contains no references to postcoloniality, despite the fact that properly global relations between former imperial centres and formally decolonized states and peoples scream of the vestiges of empire in almost every act. Postcolonies are also 'global performance states' in so far as their elites demand recognition of their distinctive claims to sovereignty at the same time as they imitate or parody former imperial powers in their everyday international relations. ${ }^{38}$

In earlier work, Owen, Heathershaw and Savin constructed a practice-based account of the production of power between dominant and subordinate actors in post-Western settings, deploying two concepts drawn from postcolonial theory - Bhabha's concept of mimicry ${ }^{39}$ and Scott's notion of $m \bar{e} t i s^{40}$ - to conceptualise the ways in which imperial or hegemonic practices are challenged, reproduced or subverted by subordinate actors at formal and informal levels. ${ }^{41}$ The essay argued that, following L.H.M. Ling, two levels of mimicry are discernible: 'formal mimicry' comprises superficial copying, while 'substantive mimicry' indicates a more profound engagement that foments a hybrid set of practices and subjectivities. ${ }^{42}$ Following Scott, mētis was conceptualised as everyday practices of subversion, enacted through 'common sense, experience, a knack'. A broad concept, it is best observed at the local level, from elegant craftsmanship to schemes for kleptocracy, in attempts to maintain virtue and attempts to exploit it. $^{43}$

Bringing this work on practices of mimicry and mētis together with an ontology of the decentred state, we can formulate a relational account of rising power. In this view, a rising power relationship is one where formal and substantive mimicry occur in the performance of state-centric agendas, but where decentred business dealings and local political-economic 
practices produce mētis, even if these effectively undermine official international agendas. The radical claim is that the two processes, which appear to work against one another, are entirely consistent providing we accept that power is not a commodity, but a relationship. This allows us to make theoretical sense of how the USA and EU have been relatively ineffective in Central Asia compared to Russia and China: it is not about what power their central governments possess but how they build relationships of public performance and mutually beneficial practices of private enrichment via statecraft at the margins. The following two sections explore this thesis, first, in the Russian case and, second, in the Chinese case.

\section{Russian Decentred Practices in Central Asia: Rusal's struggles and the EAEU}

Globally, the Kremlin's claims to Russia's rising power status relies upon the public performance by state apparatus of its post-imperial hegemony in its so-called 'near abroad', including in Central Asia. This performance is also entertained by local actors who produce power through shared norms and understandings: as Ortmann writes, 'insofar as Russian power is pervasive and persuasive, it is because the Kyrgyz - state elites and population - are actively involved in its perpetuation. ${ }^{44}$ Post-Soviet Central Asian governments formally mimic Russian laws and join Russian-led institutions, reproducing the 'post-Soviet' regional identity. ${ }^{45}$

Our first example considers Russia's relationship with post-Soviet Tajikistan, which has typically been interpreted by Western geopolitical commentators as one centred on grand strategy, geopolitical competition and national interests. Yet, our research shows that key episodes in national-level Russian-Tajik relations have been driven more by mimicry and mētis between the countries' business and political elites than by grand strategy. ${ }^{46}$ When Vladimir Putin and President Emomali Rahmon of Tajikistan attended a major bilateral meeting in Sochi 
in July 2004, it seemed that an international grand bargain had prioritised the return of the Russian-owned United Company Rusal into the Tajik aluminium industry ahead of its Western rivals. This deal also included the transfer of Tajikistan's southern border from Russian to Tajik control, the status of Russia's space observation centre in Nurek and Tajikistan's debt to Russia. The agreement concerning the Tajik Aluminium Company (Talco) was especially important for Rahmon and his allies since he was intending to replace the previous management - and their offshore arrangement via the BVI registered company Ansol - with family members, their business allies and a new offshore set-up. Following an August 2004 meeting between Rusal's head Deripaska and Rahmon, they apparently conspired to expel Ansol from its partnership with Talco (which, as stated in a subsequent high court ruling, was unlikely to be for Talco's benefit since it was probably operating at a 'significant loss'). ${ }^{47}$ The new arrangement was ordered by a presidential decree of 23 December 2004, allowing the ownership of aluminium to be transferred from Talco to an offshore company known as 'CDH'. I In return Talco received a small tolling fee for its work in processing the alumina. ${ }^{48}$

What appeared to be a geopolitical triumph for the Russian leadership was actually driven not by traditional geopolitics, but by highly decentred relations and practices. The mētis of Rusal, which had emerged from the Soviet state entities that had built the Tajik smelter in 1975, and which had been trading with Tajikistan as a private company since 1996, had been instrumental in the company's triumph over its Western rival. Offshore companies with which Rusal had been in trading relations for nearly a decade provided the basis for new gate-keeping relations and rent-seeking practices. The deal was also highly contingent on the approval of patronal networks, regardless of what had been formally agreed between Putin and Rahmon. By early 2005, the new arrangement had already begun to sour with the Government of Tajikistan's allegation of fraud against Rusal. 
In 2006, Talco shifted partners again, this time with Norway's Hydro Aluminium - part of Norsk Hydro, a conglomerate whose majority shareholder is the Government of Norway. This was an interim arrangement that would precipitate a full reorganization of Tajikistan's major state industry via offshores vehicles. After a June 2006 settlement between Talco and Hydro, the latter became Talco's principal partner, ousting its rival Rusal. An agreement signed in Dushanbe on 20 December 2006 committed Hydro to longer-term investment and a possible tripling of the production capacity of the Soviet-era plant. ${ }^{49}$ Thus, despite Russian-Tajik diplomatic relations reaching the height of the Sochi deal of 2004, the most significant Russian investment in Tajikistan was breaking down. After 2006, Rusal's struggle with Talco and the Tajik state continued in international courts of arbitration for at least a further eight years as Rusal subsidiaries eventually succeeded - via the New York court room in 2014 - in forcing open the accounts of the Tajik offshore companies and causing disruption in Russian-Tajik relations. ${ }^{50}$ This case suggests that, in so far as the Russian government retains leverage over its Tajikistani counterpart, it is as much due to these global and decentred practices involving Russian and Tajik elites in courts and business meetings as it is in the bilateral deals and projections of power from the Kremlin.

These practices of mimicry and mētis continue to be constitutive of Russia's relations in Central Asia. Consider the Kremlin's efforts to enhance Russia's 'rising power' status by establishing the Eurasian Economic Union (EAEU). The EAEU is widely seen as formally modelled on the European Union, although its content, or practices, differ substantially. ${ }^{51}$ It can therefore be seen as a textbook example of institutional mimicry. Indeed, Putin himself refers to the EU as an important model for the project. ${ }^{52}$ At the same time, it comprises substantive mimicry: Dragneva and Wolzuk argue that the EAEU is the vehicle through which 
Russia engages in 'normative rivalry' with the EU - an attempt to lure post-Soviet states away from the EU's westernising influence. ${ }^{53}$ In the words of Russian scholar, Alexander Lukin, 'If the countries of Europe united to champion the values of democracy, human rights, and economic cooperation, then a Eurasian union must stand for its own ideals, too. ${ }^{, 54}$

Despite the creation of numerous supranational co-ordinating bodies, an integrated economic zone via the EAEU has not materialised, ${ }^{55}$ and intra-regional trade and investment has declined. ${ }^{56}$ Reports show that Kyrgyzstan has seen a near $20 \%$ fall in trade turnover with other EAEU member states, ostensibly due to poor regional economic conditions, while the competitiveness of Russian products in member states' markets has diminished. ${ }^{57}$ As Dragneva and Wolczuk argue, 'The poor governance characterizing [EAEU] member states, including Russia, creates a formidable obstacle to the effective functioning of the union as a rules-based regime' ${ }^{58}$ The point here is not that the EAEU has simply been poorly implemented, but that it was both preceded and is shaped by a basket of institutional and substantive mimicries and everyday practices of mētis, ensuring that it would not take the coherent form centred on state parties that was envisaged in its treaties and surrounding political discourse. Similar arguments have been made with regard to the CSTO, where Russian officials have demanded unquestioning loyalty rather than functional strategic cooperation. ${ }^{59}$

The run-up to the signing of the foundational EAEU Treaty on May 29, 2014, was characterized by Russian negotiators offering various concessions - both exemptions within the treaty and as bilateral side payments - to other prospective members. Accordingly, even though Russian officials went to great lengths to present the EAEU as a typical regional Russian-led Eurasian integration effort, securing agreement to the foundational treaty was predicated on offering tailored political and economic incentives to key elites in accession states. Hence, Belarus's 
President Alexander Lukashenko only agreed to sign the treaty after he was given assurances that Minsk would keep 50\% of duties it used to transfer to Russia for re-exporting oil products, based on subsidized Russian oil, to third countries. ${ }^{60}$ Armenia was awarded continued discounts on Russian gas imports and over 900 exemptions on tariffs of politically-sensitive consumer goods. ${ }^{61}$ Kyrgyzstan was also offered a number of inducements, including writing off a $\$ 300$ million in bilateral debt and accessing a special $\$ 1$ billion development fund, allocated by the Russian federal budget (comprised of $\$ 500$ million in grants and $\$ 500$ million in concessionary loans), which reportedly went directly went to the National Bank of Kyrgyzstan. ${ }^{62}$ This financing made the Russian Federation the country's leading bilateral donor and, according to the fund's public statements, ${ }^{63}$ has supported projects including the renovation of Manas international airport and the construction of a hydro power plant, both sectors that have been marred by graft scandals.

In sum, while in the Kremlin's discourse the Russian state may appear as highly centred and strategic actor, when 'Moscow' does act, it is often not according to official Kremlin strategy but in the form of profoundly decentred state-owned enterprises that operate across informal and cross-regional business networks. ${ }^{64}$

\section{Chinese Decentred Practices in Central Asia: CNPC, CDB and the BRI's expansion}

In this final section, we argue that China's rise in Central Asia demonstrates processes of both mimicry and mētis. However, given China's relative independence from Western norms and institutions compared to Russia, we find fewer instances of mimicry of either formal or substantive kinds. Nevertheless, traces of substantive mimicry may be found in China's use of bilateral investments and international financial institutions to reshape economic norms and fill the space vacated by a retreating West. ${ }^{65}$ Importantly, these same actors rely on the mētis of 
local partners to invest in the region and push Beijing to post hoc rationalization in the form of SREB announcements. ${ }^{66}$ While Chinese government discourse emphasises 'win-win' cooperation via a centrally controlled development strategy, the increasing autonomy of Chinese SOEs render local practices of bribery and corruption endemic to Chinese projects in neighbouring countries, including in Central Asia. ${ }^{67}$ The win-win here appears to be primarily for networks of Chinese and Central Asian business elites.

Multiple cases of Chinese investments and infrastructure projects both before and after the announcement of SREB/BRI suggest that Chinese-sponsored development in Central Asia builds graft opportunities for Chinese and local elites into the templates of their legitimate financial agreements. Road building, for example, provides the classic model of corruption in Central Asia. The Dushanbe-Chanak highway in Tajikistan was built with Chinese funding and opened in 2010 with its toll booths operated by an offshore-registered company, Innovative Road Solutions, with no previous history of highway projects and which was estimated to be funnelling \$25-\$30 Million per annum into accounts whose beneficiaries were members of the government's inner circle. ${ }^{68}$ Similarly, in June 2018, local investigative reporting in Kyrgyzstan revealed that an $\$ 850$ Million BRI project under the Export-Import (Exim) Bank of China to build a new North-South highway was riddled with corruption schemes where Kyrgyz ministers colluded with the Chinese contractor to ensure that over-payments were built into the project. ${ }^{69}$ Both before and after the BRI announcement, it appears that pay-offs to local elites are central to Chinese strategy in Central Asia.

More emerging evidence about the financial and commercial structuring of BRI projects suggests that these centring and decentring aspects can also inter-relate. In 2018, former Kyrgyz Prime Minister Sapar Isakov faced corruption charges relating to the faulty 
redevelopment of Bishkek's power plant by Chinese company Tebian Electric Apparatus Stock Co. Ltd. (TBEA) which deprived thousands of residents of heating over the especially cold winter of 2017/18. There had been no tender process for the $\$ 386$ Million contract financed via China's EximBank. ${ }^{70}$ 'The choice of TBEA,' Isakov explained in his parliamentary testimony, before his forced resignation, 'was the official position from China and we could not change this. ${ }^{71}$ However, TBEA contracted the Kyrgyz private company Electrical Stations, paying fees for goods far in excess of their market value, thereby enabling \$100 Million of embezzlement for Kyrgyz as well as Chinese business, while failing to adequately invest in chemical treatment units that were necessary for the operation of the plant's boilers. ${ }^{72}$ In Kyrgyzstan, where investigative journalism and active civil society survive, the controversy continues with former President Almaz Atambaev now accused. ${ }^{73}$

For Chinese business there may be strategic payoff from these micro practices. Such inflated contracts create the risk of greater dependency on China as creditor, thereby fuelling China's rise through debt diplomacy, as some recipients of BRI investments become insolvent due to their repayment obligations. ${ }^{74}$ In Tajikistan, for example, the government repaid its debt to TBEA for the redevelopment of the Dushanbe-2 power plant by handing over a gold mine to the contractor. ${ }^{75}$ Chinese leaders have demonstrated substantive mimicry of Western financial practices in their justifications, lamenting, 'It is unreasonable that money coming out of Western countries is praised as good and sweet, while coming out of China it's sinister and a trap' ${ }^{76}$ Such counter arguments are reasonable in that it is Chinese private companies that appear to be the primary beneficiaries of recipient states' indebtedness in Central Asia. It is a matter of conjecture at this stage as to whether this a part of Beijing's grand strategy. 
What is at the top of the Chinese agenda in Central Asia is development of the region's oil and gas. ${ }^{77}$ China has built major new energy pipelines in Central Asia that have transformed the region's export infrastructure away from its previous colonial orientation towards Russia, notably an oil pipeline traversing Kazakhstan and a network of gas connectors, known as China-Central Asia pipeline, that transports gas from Turkmenistan, through Uzbekistan and Kazakhstan before crossing into Xinjiang to flow into Chinese East-West pipeline. ${ }^{78}$ Between 2002 and 2012, Chinese oil companies went on a spending boom overseas, making more than 150 deals and over $\$ 120$ billion worth of investments to acquire a variety of overseas holdings. ${ }^{79}$ The financial crisis of 2008-09 was an important marker, as it ushered in numerous new overseas acquisitions and loans-for-energy agreements between China and cash-strapped Eurasian and Latin American governments. ${ }^{80}$ The foremost agent in these projects has been China National Petroleum Company (CNPC), a state-owned enterprise and the country's largest energy company), whose subsidiary Petrochina is the world's fourth largest oil producer. $^{81}$

This new energy infrastructure has been accompanied by a set of major loans-for energy deals via China Development Bank $(\mathrm{CDB})$ that have made China an important regional investor and creditor. ${ }^{82}$ The Turkmen-China gas pipeline, in particular, has turned Turkmenistan into a critical exporter for Beijing and has vaulted CNPC over the Russian giant Gazprom, formerly the regional monopolist, as Central Asia's main gas producer and distributor. A great deal of CNPC's projects in Central Asia have been financed via the CDB which has funnelled state development funds to assist in acquisition of overseas energy assets. ${ }^{83}$ In Kazakhstan and Turkmenistan, loans from the CDB were used to structure deals worth $\$ 8$ billion and $\$ 10$ bn (to become \$13bn in 2013 when CNPC also acquired a stake in the large Kashagan international consortium) respectively, guaranteeing Chinese oil companies access to the Turkmen gas 
supplies and shares in Kazakh energy companies in return. In January 2018, the bank announced that it would commit $\$ 250 \mathrm{Bn}$ to projects associated with BRI. ${ }^{84}$

However, these vital trans-regional energy projects are no less prone to graft opportunities between elites. In 2013, Chinese authorities launched an unprecedented crackdown and investigation of corruption in CNPC. The investigation had touched upon the company's overseas activities in Turkmenistan (among other overseas locations), and had implicated two major executives who had previously headed major subsidiaries in Central Asia, including, Liao Yongyuan, former vice-president of PetroChina, who in 2017 was convicted and sentenced to 15 years in prison on corruption charges. ${ }^{85}$ That the Chinese government itself seeks to stamp out corrupt activities demonstrates that such practices are not part of a coordinated grand scheme by Beijing; rather, they constitute practices of mētis, operating at the local limits of the reach of central state organs.

Much of these rents are gathered by political elites in Central Asia who serve as gate-keepers to China's BRI. This role is exemplified in CNPC's deal to acquire one of Kazakhstan's largest energy companies, Aktobe MunaiGaz. A Wall Street Journal investigation, based on materials and allegations originally made by exiled political dissident Mukhtar Ablyazov and published in Kazakh independent newspapers, found that the 2003 acquisition of Aktobe by CNPC had been mediated by a holding company registered in the British Virgin Islands, CNPC International Caspian Limited (CICL). ${ }^{86}$ CICL's start-up capital was reportedly just $\$ 100$, while it proceeded to sell at a later date a $49 \%$ stake (for $49 \$$ ) to yet another BVI-registered company Darley Investment Services. Over the next 2 years, CNPC bought back Darley's stakes in the company for $\$ 165.90$ million, netting the beneficial owners of the company an 
enormous profit from the company's initial $\$ 49$ outlay. According to the report, the structured deal yielded a $\$ 150$ million payoff to a business partner of the President's son-in-law. ${ }^{87}$

How might we assess these cases in light of our decentred, relational ontology and our interpretive concepts of mimicry and mētis? In heuristic terms, government actors and SOEs deploy mimicry in their business culture, whereby they appeal to internationally accepted norms of financial conduct, while the brokers and deal-makers employ mētis in the financial transactions themselves. 'Knack' and 'local knowledge' is found in the marrying of the inner knowledge of clientelistic networks with the technical knowledge of transnational finance and the ability to circumvent the anti-money laundering laws to which it is putatively subject. A decentred but still elitist approach to China's rise in Central Asia helps us see that 'corruption' is not a bump on the road but part of the infrastructure built in to BRI projects - in spite of Beijing's efforts to eliminate it - and demonstrates the way in which local power flows through these networks. This decentred perspective recognises that one grandiose pronouncement of a singular \$1 Trillion global scheme is less significant than the thousand times one hundred million dollars is stolen in specific places and times across the globe. When we move beyond the centred discourse and hierarchical relations promulgated by rising powers, we may see these acts of embezzlement and graft as productive of networked relations and horizontal between transnational elites and sovereign debt dependencies between states.

\section{Conclusion}

We have sought to demonstrate that the two dynamics of mimicry and mētis are central to any study of the rise and fall of powers. We have taken our examples from over a 15-year period to demonstrate the continuity in these practices and the fact that they precede the EAEU and BRI initiatives. These practices are at times sufficiently unstable as to trigger a fall in power 
(as in Rusal and Talco in 2005-2006) and at times sufficiently stable as to be co-constitutive of rise (as in the case of $\mathrm{CNPC}, \mathrm{CDB}$ and the BRI over the last decade). The concepts of mimicry and mētis apply at the levels of both institutional design and everyday trade and investment practice to elaborate the processes of state transformation identified by Jones and Hameiri with respect to global governance. But an explanation of whether they work for or against the rise of an aspiring great power may be found in the extent to which they achieve the buy-in of elite networks rather than satisfy their putative national interests. Grand strategy may give the appearance of a highly centred and traditional geopolitics. However, in practice, both mimicry and mētis generate dynamics where the margins of EAEU and BRI matter as much as their centres.

Greater research in the form of ethnographies of transnational finance and multinational enterprises are required to properly evidence the nature and scale of rising power in decentred terms. Anthropological research has taken this de-centred approach further by considering Central Asian-Chinese trade as a mode of 'everyday diplomacy ${ }^{88}$ which contrasts with the 'romantic visions of interconnectivity fashioned by elites which gather in international hotels'. In fact, argues Marsden, 'it is in the markets and bazaars in which commerce and exchange actually take place where connectivity is actually fashioned' ${ }^{89}$ By shifting our optic to the decentred relations of political elites we can see the rent-seeking opportunities which are invariably built into these projects but are, for obvious reasons, difficult to observe. Such mechanisms connect local patron-client relations to transnational financial processes and their offshore vehicles. These decentring process are not only the means by which powers rise but themselves constitute the rising. In this sense, 'rising powers' are vehicles for the enrichment of new global networks of elites. Their rises are themselves contingent upon discourses which provide a veneer of legitimacy and practices which enable a decentred network actors to gain 
political status and personal wealth. We must stop thinking of rising powers as concentrations of power and begin effectively conceiving them as relations of power which flow through transnational, state-business networks.

\section{Acknowledgements}

This work was supported by the Economic and Social Research Council (UK) under Grant ES/J013056/1

\section{Declaration of interest statement}

None

\section{Endnotes}

\footnotetext{
${ }^{1}$ Megoran and Sharipova, Central Asia in International Relations; Fingar, The New Great Game.

${ }^{2}$ This is also sometimes called One Belt One Road (OBOR) in English, which is a more direct translation of the project's Mandarin Chinese appellation.

${ }^{3}$ Cooley and Heathershaw, Dictators Without Borders; Cooley, Great Games, Local Rules.

${ }^{4}$ Hood, 'A public management for all seasons'; Majone, 'From the Positive to the Regulatory State'; Aucoin,

'Administrative reform in public management'.

${ }^{5}$ Jessop, The State; Jessop, 'Towards a Schumpeterian Workfare State?'.

${ }^{6}$ Cooley, Great Games, Local Rules; ${ }^{6}$ Cooley and Heathershaw, Dictators Without Borders; Heathershaw, 'The global performance state'; Heathershaw and Schatz, Paradox of Power; Owen, 'A Genealogy of Kontrol' in Russia'; Owen and Bindman 'Civic Participation in a Hybrid Regime'.

${ }^{7}$ Owen et al. 'How Postcolonial is Post-Western IR?'

${ }^{8}$ Kaczmarski, 'Non-Western Visions of Regionalism'

${ }^{9}$ Wilson, 'The Eurasian Economic Union and China's silk road'; Indeo, 'The Eurasian Economic Union and the Silk Road Economic Belt'.

${ }^{10}$ Cooley, Great Games, Local Rules, 66.

${ }^{11}$ Mearsheimer, 'Why Ukraine is the West's Fault'.

${ }^{12}$ Weitz, 'The Customs Union and Eurasian Union'.

${ }^{13}$ Dragneva and Wolczuk, 'The Eurasian Economic Union', 17.

${ }^{14}$ Putin, 'Novyi integratsionnyi proekt dlya Evrazii'.

15 Putin, 'Plenarnoye zasedanie Peterburgskogo mezhdunarodnogo ekonomicheskogo foruma'.

${ }^{16}$ Kaczmarski, 'Non-Western Visions of Regionalism'.

${ }^{17}$ Jones and Zeng, 'Xi Jinping's Limited Impact on China's Foreign Policy-Making'

${ }^{18} \mathrm{Xi}$, 'Promote Friendship Between Our People and Work Together to Build a Bright Future'.

${ }^{19}$ NDRC, Vision and Actions on Jointly Building Silk Road Economic Belt.

${ }^{20}$ These included: three land routes (to Europe via Central Asia/ Russia; to the Middle East via Central Asia; and to India via Southeast Asia); two maritime routes (to Europe via the South China Sea and Indian Ocean, and to the South Pacific via the South China Sea), and six "corridors" (the New Eurasian Land Bridge, ChinaMongolia-Russia, China-Indochina, China-Central Asia-West Asia, China-Pakistan, and Bangladesh-ChinaIndia-Myanmar). For discussion, see also: Foreign Affairs Select Committee, Written Evidence from Dr Lee Jones
} 
${ }^{21}$ Jones and Zeng, 'Xi Jinping's Limited Impact on China's Foreign Policy-Making', this volume

${ }^{22}$ Kaczmarski, 'Non-Western Visions of Regionalism'.

${ }^{23}$ Ortmann, 'The post-Soviet Myth of the Strong State in Russia'.

${ }^{24}$ Hameiri and Jones, 'Rising Powers and State Transformation'.

${ }^{25}$ Scott, Domination and the Arts of Resistance; Mitchell,

${ }^{26}$ Hameiri and Jones, 'Rising Powers and State Transformation', 80.

${ }^{27}$ Owen, 'A Genealogy of Kontrol' in Russia'. See also Jessop, 'Towards a Schumpeterian Workfare State?'.

${ }^{28}$ Owen, Heathershaw and Savin, 'How Postcolonial is Post-Western IR'?

${ }^{29}$ Hameiri and Jones, 'Rising Powers and State Transformation'. See also Zheng, Globalization and State

Transformation in China.

${ }^{30}$ Hameiri and Jones, 'Rising Powers and State Transformation, 89.

${ }^{31}$ Hale, Patronal Politics.

${ }^{32}$ Tkachenko, 'Regionalization of Russian Foreign and Security Policy'; Sharafutdinova, 'Paradiplomacy in the Russian Regions'.

${ }^{33}$ Dawisha, Putin's Kleptocracy.

${ }^{34}$ Ortmann, 'The Russian network state as a great power'.

${ }^{35}$ Cooley and Heathershaw, Dictators Without Borders.

${ }^{36}$ Galeotti, The Vory. See also Sharaftudinova,'The dynamics of global-domestic institutional interaction', 3; Sharafutdinova and Dawisha, 'The Escape from Institution-Building in a Globalized World'.

${ }^{37}$ Adler and Pouliot, International Practices, 5.

${ }^{38}$ Heathershaw, 'The global performance state'.

${ }^{39}$ Bhabha, The Location of Culture.

${ }^{40}$ Scott, Seeing Like a State.

${ }^{41}$ Owen, Heathershaw and Savin, 'How Postcolonial is Post-Western IR?'.

${ }^{42}$ Ling, 'Chapter 5 '.

${ }^{43}$ Scott, Domination and the Arts of Resistance; Mitchell, 'The Limits of the State'

${ }^{44}$ Ortmann, 'Beyond Spheres of Influence'.

${ }^{45}$ Owen, Heathershaw and Savin, 'How Postcolonial is Post-Western IR?'.

${ }^{46}$ For more detail on the Talco case see Cooley \& Heathershaw, ch.4

${ }^{47}$ BALII, Tajik Aluminium Plant v Ermatov \& Ors, para 22-23.

${ }^{48}$ Ibid., para 182.

${ }^{49}$ Ibid.

${ }^{50}$ International Court of Arbitration, Hamer Final award, In The Matter Of An Arbitration Pursuant To The

Swiss Rules Of International Arbitration Of International Arbitration, case no. 600097-20079 (October 2013)

${ }^{51}$ Aslund, 'Putin Gets It Wrong Again'.

${ }^{52}$ Gardner, 'Putin Praises Eurasian Economic Union'.

${ }^{53}$ Dragneva and Wolczuk, 'Russia, the Eurasian Customs Union and the EU', 9.

${ }^{54}$ Lukin, 'What the Kremlin is Thinking', 91.

${ }^{55}$ Weitz, 'The Customs Union and Eurasian Union: A Primer'; Dragneva and Wolczuk, 'The Eurasian

Economic Union'.

${ }^{56}$ Frolovskiy, 'Kyrgyzstan Turns to China'.

${ }^{57}$ Kudryavtseva, 'Poltora goda Kyrgyzstana v EAES'

${ }^{58}$ Dragneva and Wolczuk, 'The Eurasian Economic Union', 17.

${ }^{59}$ Allison, 'Protective Integration and Security Policy Coordination'.

${ }^{60}$ Vysotskaya and Viera 'Eurasian Integration', 574-75.

${ }^{61}$ Ter-Matevosyan et al. "Armenia in the Eurasian Economic Union', 349

${ }^{62}$ Vysotskaya and Viera 'Eurasian Integration', 574-75.

${ }^{63}$ Russian-Kyrgyz Development Fund, "Mission, Goals and Tasks." Available at:

http://www.rkdf.org/en/about_us/mission_goals_and_tasks

${ }^{64}$ Kononenko and Moshes, Russia as a Network State.

${ }^{65}$ Zeng, 'Chinese Views of Global Economic Governance'.

${ }^{66}$ See also Hameiri and Jones, 'Rising Powers and State Transformation'.

${ }^{67}$ See Jones and Zou, 'Rethinking the Role of Stateowned Enterprises in China's Rise'.

${ }^{68} \mathrm{RFE} / \mathrm{RL}$, 'Tajik President's Son-in-Law Denies Ties to Company'.

${ }^{69}$ Aidar, 'Kyrgyzstan's north-south road to corruption'.

${ }^{70}$ Putz, 'The Bishkek Power Plant Saga'.

${ }^{71}$ Djanibekova, 'Power plant blame game threatens political showdown'.

${ }^{72}$ TAG News, 'Pri modernizatsiyi TETs byili ukradenyi \$100 mln. Utverzhdayoot deputati', 16 May 2018, available at: https://www.kyrtag.kg/ru/news/pri-modernizatsii-tets-byli-ukradeny-100-mln-utverzhdayut- 
${ }^{73}$ Alkanova, 'Abuse of Power?'

${ }^{74}$ Hurley et al, 'Examining the Debt Implications of the Belt and Road Initiative'.

${ }^{75}$ Kaktus Media, 'Tadzjikistan rasplatilsya c Kitaem za remont TETs zolotorudnym mestorozhdeniem; see also

Aidar, 'Kyrgyzstan's North-South Road to Corruption'.

${ }^{76}$ Griffiths, 'Are the Wheels Coming off China's Belt and Road Mega Project?'

${ }^{77}$ The succeeding paragraphs are based on Cooley and Heathershaw (2017), pp.181-185

${ }^{78}$ Eder, 'China-Russia Relations in Central Asia'; Paik Sino-Russian Oil and Gas Cooperation.

${ }^{79}$ Paige et al. 'Powerful Oil Clique and the Centre of Chinese Probes'.

${ }^{80}$ Downs Inside China, Inc.

${ }^{81}$ Lague et al. 'Inside Xi Jinping's Purge of Oil Mandarins'.

${ }^{82}$ Downs, Inside China, Inc.

${ }^{83}$ Sanderson and Forsythe, China's Superbank.

${ }^{84}$ Sun, 'China Development Bank commits $\$ 250$ bn to Belt and Road'.

${ }^{85}$ Reuters, 'China jails former senior oil executive for 15 years for graft'.

${ }^{86}$ Wall Street Journal, 'Kazakh Spat Casts Light on China Deals'.

${ }^{87}$ Chazan, 'Kazakh Spat Casts Light on China Deals'.

${ }^{88}$ Marsden et al. 'Everyday Diplomacy'.

${ }^{89}$ Marsden, 'Actually existing silk roads', 31 .

Bibliography

Adler, E. and V. Pouliot. "International practices.” In International Practices, edited by E. Adler and V. Pouliot, 3-35. Cambridge: Cambridge University Press, 2011.

Aidar, S. "Kyrgyztan's North-South Road to Corruption", OpenDemocracy, 9 August 2018. Available at: https://www.opendemocracy.net/od-russia/satina-aidar/kyrgyzstansnorth-south-road-to-corruption

Alkanova, E. "Abuse of power? On the trail of China's mystery millions in Kyrgyzstan", OpenDemocracy, 24 October 2018, Available at: https://www.opendemocracy.net/od-russia/elnura-alkanova/what-happened-atbishkek-power-plant

Allison, R. "Protective Integration and Security Policy Coordination: Comparing the SCO and CSTO”, The Chinese Journal of International Politics, 11, no. 3 (2018): 297-338.

Aslund, A. "Putin Gets It Wrong Again: Eurasian Economic Union Hurts Russia", Atlantic Council, 1 February 2016. Available at: http://www.atlanticcouncil.org/blogs/ukrainealert/putin-gets-it-wrong-again-eurasianeconomic-union-hurts-russia.

Aucoin, P. "Administrative reform in public management: paradigms, principles, paradoxes and pendulums", Governance 3 no. 2 (1990): 115-137.

BALII. "Tajik Aluminium Plant v Ermatov \& Ors", EWHC 2241, 21 October 2005, para 2223. Available at: http://www.bailii.org/.

Bakhtin, M. The Dialogic Imagination, Austin: University of Texas Press, 1982.

Bhabha, H. K. The Location of Culture,Abingdon: Routledge, 1994. 
Cardenal, J. P. and H. Araújo China's Silent Army: The Pioneers, Traders, Fixers and Workers Who Are Remaking the World in Beijing's Image, trans. C. Mansfield, London: Penguin, 2013.

Chazan, G. "Kazakh Spat Casts Light on China Deals”, Wall Street Journal, 26 March 2010. Available at: https://www.wsj.com/articles/SB10001424052748703580904575131611702788550.

Cooley, A. and J. Heathershaw, Dictators Without Borders: Power and Money in Central Asia. New Haven: Yale University Press, 2017.

Cooley, A. Great Games, Local Rules: The New Great Power Contest in Central Asia. Oxford: Oxford University Press, 2012.

Dawisha, K. Putin's Kleptocracy: Who Owns Russia? New York: Simon and Schuster, 2014.

Downs, E.S. Inside China, Inc: China's Development Bank's Cross-border Energy Deals. Washington DC John L. Thornton China Center at Brookings, 2011.

Dragneva, R. and K. Wolczuk. "Russia, the Eurasian Customs Union and the EU: Cooperation, Stagnation or Rivalry?" Chatham House Briefing Paper, London: Royal Institute of International Affairs, 2012. Available at: https://www.chathamhouse.org/publications/papers/view/185165.

Dragneva, R. and K. Wolczuk. "The Eurasian Economic Union: Deals, Rules and the Exercise of Power', Chatham House Briefing Paper, London: Royal Institute of International Affairs, 2017. Available at: https://www.chathamhouse.org/sites/files/chathamhouse/publications/research/201705-02-eurasian-economic-union-dragneva-wolczuk.pdf.

Djanibekova, N. "Kyrgyzstan: Power plant blame game threatens political showdown", Eurasianet.org, 18 May 2018. Available at: https://eurasianet.org/kyrgyzstan-powerplant-blame-game-threatens-political-showdown.

Eder, T. S. China-Russia Relations in Central Asia: Energy Policy, Beijing's New Assertiveness and 21st Century Geopolitics, Heidelberg: Springer, 2014.

Fingar, T. Ed. The New Great Game: China and South and Central Asia in the Era of Reform Stanford, CA: Stanford University Press, 2016.

Foucault, M. Discipline and Punish: the birth of the prison, trans. A, Sheridan. New York: Vintage, 1977.

Foreign Affairs Select Committee (2017). Written evidence from Dr Lee Jones (Queen Mary, University of London), Dr Jinghan Zeng (Royal Holloway, University of London), and Dr Shahar Hameiri (University of Queensland) in our capacity as academic experts (CIR0002). December 2017, available at: http://data.parliament.uk/writtenevidence/committeeevidence.svc/evidencedocument/f oreign-affairs-committee/china-and-the-international-rulesbasedsystem/written/75536.html 
Frolovskiy, D. “Amid Russian Downturn, Kyrgyzstan Turns to China”, The Diplomat, 14 July 2016. Available at: https://thediplomat.com/2016/07/amid-russian-downturnkyrgyzstan-turns-to-china/.

Galeotti, M. The Vory: Russia's Super Mafia. New Haven: Yale University Press, 2018.

Gan, N. "China's state owned firms warned to keep closer watch on overseas investments." South China Morning Post, 18 June 2015. Available at: http://www.scmp.com/news/china/policies-politics/article/1823207/chinas-stateowned-firms-warned-keep-closer-watch.

Gardner, A. "Putin Praises Eurasian Economic Union". Politico, 6 May 2014. Available at: https://www.politico.eu/article/putin-praises-eurasian-economic-union/.

Griffiths, J. “Are the Wheels Coming off China's Belt and Road Mega Project?” CNN, 31 December 2018. Available at: https://edition.cnn.com/2018/12/31/asia/china-kenyabelt-road-bri-intl/index.html.

Hale, H. Patronal Politics: Eurasian Regime Dynamics in Comparative Perspective. Cambridge: Cambridge University Press, 2015.

Hameiri, S. and L Jones. "Rising Powers and State Transformation: The Case of China". European Journal of International Relations, 22 no. 1 (2016): 72-98.

Hameiri, S. and L Jones. "Global Governance as State Transformation". Political Studies, 64 no. 4 (2016): 793-810.

Hameiri, S. and L Jones. Governing Borderless Threats: Non-Traditional Security and the Politics of State Transformation, Cambridge: Cambridge University Press, 2015.

Heathershaw, J. "The global performance state; rethinking Central Asia's 'weak states'.” In Ethnographies of the State in Central Asia: Performing Politics, edited by M. Reeves, J. Rasanayagam and J. Beyer. Bloomington: Indiana University Press, 2014.

Heathershaw, J. and E. Schatz (eds.) Paradox of Power: Logics of State Weakness in Eurasia. Pittsburgh: Pittsburgh University Press, 2017.

Hood, C. “A Public Management for All Seasons”. Public Administration, 69, no. 1 (1991): 3-19.

Hurley, J., S. Morris and G. Portelance. "Examining the Debt Implications of the Belt and Road Initiative from a Policy Perspective", CGD Policy Paper 121, Centre for Global Development, March 2018. Available at: https://www.cgdev.org/sites/default/files/examining-debt-implications-belt-and-roadinitiative-policy-perspective.pdf.

Inayatullah, N. and D. Blaney. International Relations and the Problem of Difference. London: Routledge, 2004. 
Indeo, F. The Eurasian Economic Union and the Silk Road Economic Belt: The Impact of Sino-Russian Geopolitical Strategies in the Eurasian Region. Maastricht School of Management: Working Paper No. $2016 / 5$ (2016).

Jessop, B. The State: Past, Present and Future. Cambridge: Polity Press, 2016.

Jessop, B. "Towards a Schumpeterian Workfare State? Preliminary Remarks on a PostFordist Political Economy”. Studies in Political Economy, 40 no.1 (1993): 7-39.

Jones, L. and J. Zeng. “Xi Jinping's Limited Impact on China's Foreign Policy-Making: The 'Belt and Road' Initiative and State Transformation" This volume

Jones, L. and Y. Zou. 'Rethinking the Role of State-owned Enterprises in China's Rise', New Political Economy 22, no.6 (2017): 743-760.

Kaczmarski, M. 'Non-Western Visions of Regionalism: China's New Silk Road and Russia's Eurasian Economic Union”. International Affairs, 93, no. 6 (2017): 1357-1376.

Kaktus Media. "Tadzjikistan rasplatilsya c Kitaem za remont TETs zolotorudnym mestorozhdeniem". Kaktus Media, 17 April 2018. Available at: https://kaktus.media/doc/373219_tadjikistan_rasplatilsia_s_kitaem_za_remont_tec_zo lotorydnym_mestorojdeniem.html.

Kononenko, V. and A. Moshes (eds.) Russia as a Network State: What Works in Russia when State Institutions Do Not? London: Palgrave MacMillan, 2011.

Kudryavtseva, Tatiana "Poltora goda Kyrgyzstana v EAES: Torgovlya padaet, vetposti ostayutsya", 24.kg, 24 January 2017. Available at:

https://24.kg/eaes/43748_poltora_goda_kyirgyizstana_v_eaes_torgovlya_padaet_vetp ostyi_ostayutsya/

Lague, D., C. Zhu and B. Kang Lim “Inside Xi Jinping's Purge of Oil Mandarins". Reuters, 24 July 2014. Available at: http://www.reuters.com/article/us-china-purge-cnpcspecialreport/inside-xi-jinpings-purge-of-chinas-oil-mandarinsidUSKBNOFT2NK20140724

Ling, L.H.M "Worlds Beyond Westphalia: Daoist Dialectics and the 'China Threat'." Review of International Studies 39, no. 3 (2013): 549-568.

Ling, L.H.M "Cultural Chauvinism and the Liberal International Order: 'West Versus Rest' in Asia's Financial Crisis". In Power, Postcolonialism and International Relations: Reading Race, Gender and Class, edited by C. Geeta and S. Nair. Abingdon: Routledge, 2004.

Lukin, A. "What the Kremlin is Thinking: Putin's Vision for Eurasia”, Foreign Affairs, 93 (2014): 85-93.

Majone, G. "From the Positive to the Regulatory State: Causes and Consequences of Changes in the Mode of Governance", Journal of Public Policy 17, no.2 (1997): 137-169. 
Marsden, M. “Actually Existing Silk Roads”, Journal of Eurasian Studies 8 (2017): 22-30

Marsden, M., D. Ibañez-Tirado \& D. Henig. "Everyday Diplomacy". Cambridge Journal of Anthropology 34, no.2 (2016): 2-22.

Mearsheimer, J. J. "Why Ukraine is the West's Fault: The Liberal Delusions that Provoked Putin”, Foreign Affairs 93 (2014): 77-89.

Megoran, N. and S. Sharipova (eds.) Central Asia in International Relations: The Legacies of Halford Mackinder. London: Hurst \& Co, 2013.

Mitchell, T. "The Limits of the State: Beyond Statist Approaches and Their Critics". The American Political Science Review 85, no.1 (1991): 77-96.

Moscow Times. "Russian Government Approves Giving \$1 Billion to Krygyz Development Fund", Moscow Times, 27 March 2015. Available at:

https://www.themoscowtimes.com/2015/03/27/russian-government-approves-giving1-billion-to-kyrgyz-development-fund

Narlikar, A. "Introduction: Negotiating the Rise of New Powers". International Affairs 89, no.3 (2013) : 561-576.

Neumann, I. Russia and the idea of Europe. Abingdon: Routledge, 1996.

NDRC. Vision and Actions on Jointly Building Silk Road Economic Belt and 21st-Century Maritime Silk Road. National Development and Reform Commission, PRC: 28 March 2015. Available at: http://en.ndrc.gov.cn/newsrelease/201503/t20150330_669367.html

Ong, A. Neoliberalism as Exception: Mutations in Citizenship and Sovereignty. Durham: Duke University Press, 2006.

Ong, A. and S. Collier (eds.) Global Assemblages: Technology, Politics, and Ethics as Anthropological Problems. Malden, MA: Blackwell Publishing, 2005.

Ortmann, S. "The Russian Network state as a Great Power" in Russia as a Network State: What Works in Russia when State Institutions do not? Edited by V. Kononenko and A. Moshes. Basingstoke: Palgrave Macmillan, 2011.

Ortmann, S. 'The post-Soviet Myth of the Strong State in Russia' in Paradox of Power: The Logics of State Weakness in Eurasia. Edited by J. Heathershaw and E. Schatz. Pittsburgh: Pittsburgh University Press, 2017.

Ortmann, S. "Beyond Spheres of Influence: the myth of the state and Russia's seductive power in Kyrgyzstan", Geopolitics 23, no. 2 (2018): 404-435.

Owen, C., J. Heathershaw and I. Savin. "How Postcolonial is Post-Western IR? Mimicry and Mētis in the international politics of Russia and Central Asia". Review of International Studies 44, no.2 (2017): 279-300. 
Owen, C. and E. Bindman "Civic Participation in a Hybrid Regime: Limited Pluralism in Policy-making and Delivery in Contemporary Russia". Government and Opposition 54, no.1 (2019): 98-120

Owen, C. "A Genealogy of Kontrol' in Russia: From Leninist to Neoliberal Governance". Slavic Review 74, no. 2 (2016): 331-353.

Paige, J., B. Spegele and W. Ma "Powerful Oil Clique and the Centre of Chinese Probes". The Wall Street Journal, 5 September 2013. Available at: https://www.wsj.com/articles/powerful-oil-clique-at-center-of-chinese-probes$\underline{1378425010}$

Paik, K-W. Sino-Russian Oil and Gas Cooperation: The Reality and Implications. Oxford: Oxford Institute for Energy Studies, 2012.

Putin, V. "Novyi integratsionnyi proekt dlya Evrazii - bydyshchee, kotoroe pozhdaetsya segodnya". Izvestiya, 3 October 2011. Available at: https://iz.ru/news/502761.

Putin, V. "Plenarnoye zasedanie Peterburgskogo mezhdunarodnogo ekonomicheskogo foruma”, 17 June 2016. Available at: http://kremlin.ru/events/president/news/52178.

Putz, C. “The Bishkek Power Plant Saga: Former Kyrgyz Prime Minister Faces Corruption Charges," The Diplomat, May 31, 2018. Available at: https://thediplomat.com/2018/05/the-bishkek-power-plant-saga-former-kyrgyz-primeminister-faces-corruption-charges/

Reshetov, R. "Torobaev: Ne Udivilos', esli podnimaetsya vopros o vykhode KR iz EAE", Vecherniy Bishkek, 15 February 2017. Available at: http://www.vb.kg/doc/355444_torobaev:_ne_ydivlus_esli_podnimetsia_vopros_o_vy hode_kr_iz_eaes.html.

Reuters. "China jails former senior oil executive for 15 years for graft", 19 January 2017, https://www.reuters.com/article/us-china-corruption-cnpc/china-jails-former-senioroil-executive-for-15-years-for-graft-idUSKBN1530TY.

RFE/RL. "Tajik President's Son-In-Law Denies Ties To Company", Radio Free Europe/Radio Liberty, 12 July 2010. Available at: https://www.rferl.org/a/Tajik_Presidents_SonInLaw_Denies_Ties_To_Company/209 7815.html

Robertson, R. "Glocalization: Time-Space and Homogeneity and Heterogeneity". In Global Modernities. Edited by M. Featherstone, S. Lash and R. Robertson. London: Sage, 1995.

Sakwa, R. Russia against the Rest: The Post-Cold War Crisis of World Order. Cambridge: Cambridge University Press, 2017.

Sanderson, H. and M. Forsythe China's Superbank: Debt, Oil and Influence - How China Development Bank is Rewriting the Rules of Finance. Singapore: John Wiley \& Sons Singapore Pte. Ltd.: 2013. 
Sassen, S. Territory, Authority, Rights: From Medieval to Global Assemblages. Princeton: Princeton University Press, 2006.

Scott, J. C. Seeing Like a State: How Certain Schemes to Improve the Human Condition Have Failed. New Haven: Yale University Press, 1998.

Scott, J. C. Domination and the Arts of Resistance: Hidden Transcripts. New Haven: Yale University Press, 1990.

Sharafutdinova, G. "Paradiplomacy in the Russian Regions: Tatarstan's Search for Statehood". Europe-Asia Studies 55, no.4 (2003): 613-629.

Sharafutdinova, G. "The dynamics of global-domestic institutional interaction in postcommunist Russia and elsewhere". Demokratizatsiya: The Journal of Post-Soviet Democratization 24, no.4 (2016): 457-473.

Sharafutdinova, G., and K. Dawisha. "The Escape from Institution-Building in a Globalized World: Lessons from Russia”. Perspectives on Politics 15, no. 2 (2017): 361-378.

Sun, N. “China Development Bank commits \$250bn to Belt and Road”. Nikkei Asian Review, 15 January 2018. Available at: https://asia.nikkei.com/PoliticsEconomy/Economy/China-Development-Bank-commits-250bn-to-Belt-andRoad?page $=1$.

TAG News. "Pri modernizatsiyi TETs byili ukradenyi \$100 mln. Utverzhdayoot deputati". TAG News, 16 May 2018, available at: https://www.kyrtag.kg/ru/news/primodernizatsii-tets-byli-ukradeny-100-mln-utverzhdayut-deputaty-

Ter-Matevosyan, V., A. Drnoian, N. Mkrtchyan, and T.Yepremyan. "Armenia in the Eurasian Economic Union: Reasons for Joining and its Consequences”. Eurasian Geography and Consequences 58, no. 3 (2017): 340-360.

Tkachenko, S. L. "Regionalization of Russian Foreign and Security Policy: The Case of St Petersburg", Working Paper No. 21, Zurich: Center for Security Studies and Conflict Research, 2002.

Vezirgiannidou, S-E. "The United States and Rising Powers in a Post-Hegemonic Global Order”. International Affairs 89, no.3 (2013): 635-651.

Vysotskaya, A., and G. Viera "Eurasian Integration: Elite Perspectives before and after the Ukraine Crisis". Post-Soviet Affairs 32, no. 6 (2015): 566-580.

Weitz, P. "The Customs Union and Eurasian Union: A Primer". In Putin's Grand Strategy: The Eurasian Union and it Discontents. Edited by S. F. Starr and S. E. Cornell, Central Asia - Caucasus Institute Silk Road Studies Paper, John Hopkins University. Available at: https://www.silkroadstudies.org/resources/1409GrandStrategy.pdf 
Wilson, J. L. "The Eurasian Economic Union and China's silk road: implications for the Russian-Chinese relationship". European Politics and Society 17, no. 1 (2016): 113132.

Xi, J. "Promote Friendship Between Our People and Work Together to Build a Bright Future". Ministry of Foreign Affairs of the People's Republic of China, 8 September 2013. Available at:

http://www.fmprc.gov.cn/mfa_eng/wjdt_665385/zyjh_665391/t1078088.shtml.

Xi, J. "Work Together to Build the Silk Road Economic Belt and The 21st Century Maritime Silk Road", Xinhua, 14 May 2017. Available at:

http://www.xinhuanet.com/english/2017-05/14/c_136282982.htm.

Zeng, J. "Chinese Views of Global Economic Governance”, Third World Quarterly. First view (2019).

Zheng, Y. Globalization and State Transformation in China. Cambridge: Cambridge University Press, 2004. 